\title{
Durable Complete Response of Colorectal Cancer Metastasis after Biochemotherapy
}

\author{
Dlouhodobá kompletní odpověd' metastázy kolorektálního \\ karcinomu po biochemoterapii
}

\author{
Honzirkova M. ${ }^{1}$, Lipska L. ${ }^{2}$, Kohout P. ${ }^{3}$, Ferda J. ${ }^{4}$, Belohlavek O. ${ }^{5}$, Buchler T. ${ }^{1}$ \\ 1 Department of Oncology, First Faculty of Medicine, Charles University and Thomayer Hospital, Prague, Czech Republic \\ 2 Department of Surgery, First Faculty of Medicine, Charles University and Thomayer Hospital, Prague, Czech Republic \\ ${ }^{3}$ Department of Internal Medicine, Thomayer Hospital, Prague, Czech Republic \\ ${ }^{4}$ Department of Medical Imaging, University Hospital and Faculty of Medicine, Plzen, Czech Republic \\ ${ }^{5}$ Department of Nuclear Medicine and PET Centre, Na Homolce Hospital, Prague, Czech Republic
}

\begin{abstract}
Summary
Background: Resection of the metastatic site is indicated but not always possible in patients with metastatic colorectal cancer ( $m C R C$ ) who achieve a partial or complete response (CR) to induction systemic treatment. CR after systemic treatment alone is uncommon, and even patients with radiologic $\mathrm{CR}$ after induction chemotherapy harbour persistent macroscopic or microscopic residual disease in more than $80 \%$ of cases. Occasionally, some metastatic lesions disappear radiologically but others persist after induction systemic treatment. The indication and extent of metastasectomy in these situations is controversial, especially regarding sites with completely regressed metastases. Case: This case report describes a patient with mCRC who achieved a long-term response after biochemotherapy and incomplete metastasectomy. One of the known liver lesions could not be removed due to its disappearance after induction biochemotherapy with FOLFOX and bevacizumab. Further adjuvant chemotherapy using the FOLFOX regimen was administered postoperatively. The patient has been meticulously followed by radiology including repeated positron emission tomography/computed tomography and magnetic resonance scans, clinical examination and tumour markers. No recurrence of cancer has been detected after a follow-up of 5 years. Results and Conclusion: CR to systemic treatment is uncommon, but this case report demonstrates that it can be durable in patients with colorectal cancer and liver metastases. This case report indicates that some patients with $\mathrm{mCRC}$ can be cured with systemic therapy only, challenging the prevailing paradigm of $\mathrm{mCRC}$ therapy.
\end{abstract}

Key words

colorectal cancer - metastasis - chemotherapy - molecular targeted therapy - diagnostic imaging
This work was supported by grant AZV 15-26535A.

Práce byla podpořena grantem AZV 15-26535A.

Tomas Buchler received lecture honoraria, research and travel grants from Roche. Other authors declare no conflicts of interest.

Tomáš Büchler obdržel honoráre za přednášky, výzkumný grant a cestovní granty od firmy Roche. Ostatní autoři nedeklarují konflikt zájmů.

The Editorial Board declares that the manuscript met the ICMJE recommendation for biomedical papers.

Redakční rada potvrzuje, že rukopis práce splnil ICMJE kritéria pro publikace zasílané do biomedicínských časopisů.

$\Xi^{\circ}$

assoc. prof. Tomas Buchler, MD, PhD. Department of Oncology First Faculty of Medicine Charles University and Thomayer Hospital Videnska 800 14059 Prague Czech Republic

Submitted/Obdrženo: 19. 10. 2016 Accepted/Přijato: 27. 11. 2016 


\section{Souhrn}

Východiska: U pacientů s metastazujícím kolorektálním karcinomem (metastatic colorectal cancer - mCRC), kteří dosáhli částečné nebo úplné odpovědi (complete response - CR) na indukční systémovou léčbu, je resekce metastatické lokalizace indikována, ale ne vždy možná. CR po samotné systémové léčbě je málo častá a dokonce i u pacientů s radiologickou $C R$ po indukční chemoterapii dochází k přetrvávající makroskopické nebo mikroskopické reziduální nemoci ve více než 80 \% případů. U některých pacientů dochází po indukční systémové léčbě k vymizení některých metastatických lézí dle radiologického vyšetření, jiné však přetrvávají. Indikace a rozsah metastasektomie v těchto situacích je kontroverzní, zejména pokud jde o místa s kompletně regredovanými metastázami. Případ: Kazuistika popisuje léčbu pacientky s mCRC, která dosáhla dlouhodobé kompletní remise po biochemoterapii a neúplné metastasektomii. Jedna ze známých jaterních lézí nemohla být odstraněna z důvodu jejího vymizení po indukční biochemoterapii FOLFOX a bevacizumab. Další adjuvantní chemoterapie režimem FOLFOX byla podána po operaci. Pacientka byla dále pečlivě sledována pomocí zobrazovacích metod vč. opakované pozitronové emisní tomografie a magnetické rezonance, klinickým vyšetřením a sledováním hladin nádorových markerů. Zatím, po 5 letech sledování, nedošlo k recidivě onemocnění. Výsledky a závěr: Kompletní odpověd' na systémovou léčbu je u mCRC neobvyklá, ale, jak ukazuje naše kazuistika, může být trvalá. Kazuistika demonstruje, že někteří pacienti s mCRC mohou být vyléčeni pouze systémovou terapií, což zpochybňuje převládající paradigma léčby mCRC.

\section{Klíčová slova}

kolorektální karcinom - metastázy - chemoterapie - molekulární cílená léčba - diagnostické zobrazování

\section{Introduction}

Complete response $(\mathrm{CR})$ to chemotherapy is uncommon in metastatic colorectal cancer (CRC). Even in patients with radiologic $\mathrm{CR}$ after induction chemotherapy, resection of the involved metastatic site is indicated if technically feasible. Persistent macroscopic or microscopic residual disease or early recurrence in situ occurred in $83 \%$ of liver metastases with apparent complete response on imaging in a study by Benoist et al. [1]. If patients with radiological CR of liver metastases do not undergo surgery, the recurrence rates are high $[2,3]$.

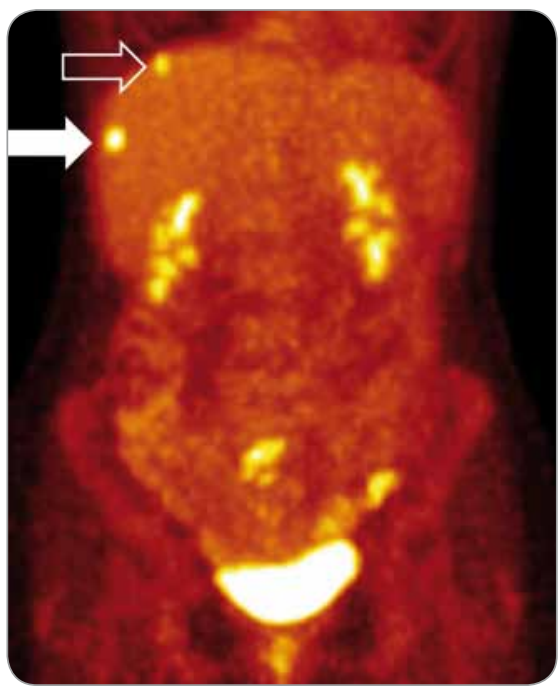

Fig. 1. PET/CT scan at diagnosis clearly showing two liver metastases (arrows). The metastasis that was not resected is marked by full arrow, the metastasis that was resected is marked by hollow arrow.
We describe a case report of a patient with two liver metastases of CRC One of the lesions was surgically resected while the other metastasis was not excised after undergoing $C R$ on induction chemotherapy. The case report demonstrates that systemic treatment can only in exceptional patients lead to complete and durable CR ("cure") in metastatic CRC (mCRC).

\section{Case report}

A 33-year-old previously healthy woman presented with crampy abdominal pain. There was no weight loss or history of

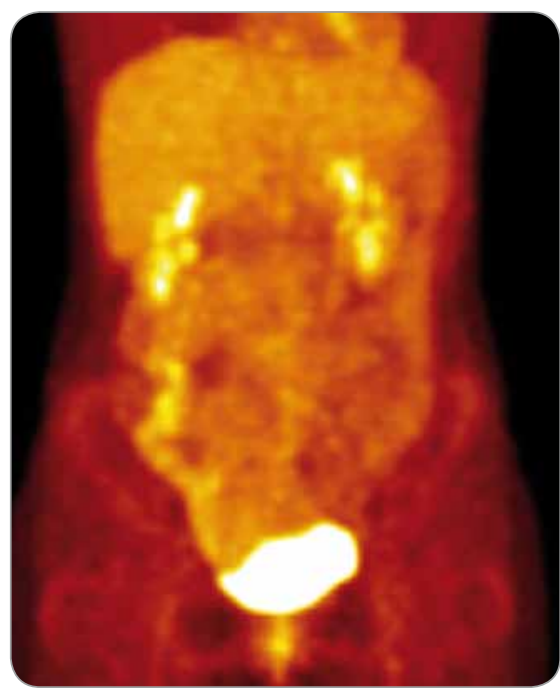

Fig. 2. PET/CT after neoadjuvant biochemotherapy - activity of liver metastases is no longer seen. rectal bleeding. She was referred to a gastroenterologist to exclude possible Crohn's disease. On abdominal ultrasonography, there was a colonic wall thickening of the descending colon and colonoscopy revealed tight stenosis in the area. A biopsy was taken and histology demonstrated grade 3 colorectal adenocarcinoma. Levels of tumour markers, including carcinoembryonic antigen (CEA) and carbohydrate antigen 19-9 (CA19-9) were not increased. There was no family history of cancer.

Left hemicolectomy with lymphadenectomy and peritoneal sampling was

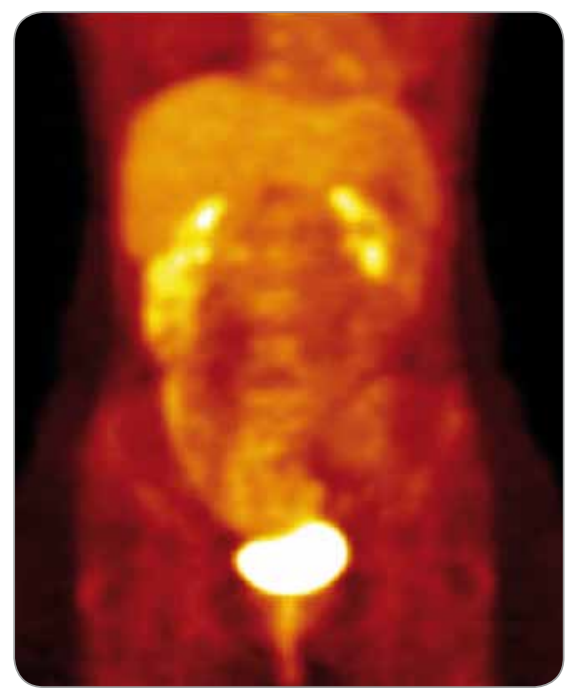

Fig. 3. PET/CT after 5-year follow-up showing ongoing complete response. 
performed. The final diagnosis was colorectal carcinoma stage pT3 pN2 (six positive lymph nodes of 32 extracted). Positron emission tomography-computed tomography (PET/CT) scan detected two liver metastases in segments VIII and $\mathrm{VI} / \mathrm{VII}$, with diameters of approximately $5 \mathrm{~mm}$ and $6 \mathrm{~mm}$, resp. (Fig. 1). Pending evaluation for possible liver metastasectomy, systemic treatment was initiated and the patients received two cycles of infusional 5-fluorouracil, leucovorin, and oxaliplatin (FOLFOX) and bevacizumab. Bevacizumab was then discontinued because of the planned hepatic metastasectomy and another cycle of FOLFOX was administered. Four months after presentation, the patient underwent non-anatomic metastasectomy of the lesion in segment VIII, but the lesion in segment VI/VII could no longer be found either by palpation or by intraoperative ultrasound. Consequently, no resection was carried out of the second metastasis. Pathologic examination of the resected liver specimen confirmed metastatic colorectal adenocarcinoma. The patient recovered well from the surgery with no signs of active disease on imaging (Fig. 2) and received a further nine cycles of FOLFOX chemotherapy. Although repeated imaging with MR and PET/CT is not routinely indicated for follow-up of mCRC patients, due to extremely high risk of relapse we did carry out monitoring using these methods which revealed no signs of relapse (Fig. 3). With a follow-up of 5 years after the completion of treatment, the patient is well and remains free of relapse.

\section{Discussion}

Most metastatic solid cancers are traditionally considered incurable with systemic treatments. Nevertheless, combination regimens that have been developed for $\mathrm{mCRC}$ provide a significant propor- tion of pathologic CRs (pCRs). The proportion of patients achieving $\mathrm{pCR}$ of liver metastases after neoadjuvant/induction chemotherapy is approximately $6-8 \%$ and these patients experience prolonged overall survival $[1,4]$. It is not known whether the addition of a targeted agent increases the rate of $\mathrm{PCR}$ in $\mathrm{mCRC}$, although such result would be expected as the response rates increase compared to chemotherapy alone [5]. Certainly, neoadjuvant biochemotherapy is feasible and safe in these patients and pCRs have been reported [6-8].

In contrast to breast cancer, there are no routinely used radiological tissue markers for liver metastases form CRC. Therefore, the disappearance of a liver metastasis can pose a formidable dilemma for the surgeon. A specific problem arises if some liver metastases regress completely on imaging and the remaining ones are resectable. The morbidity and mortality of liver metastasectomy is not negligible, however it represents the only curative option in this situation. Some surgeons would resect only the radiologically visible lesions while others would refrain from operating. Our case report shows that to operate in such circumstances is not unreasonable and cures may result from such a strategy, albeit in a minority of patients.

In addition, other aetiology of liver lesions needs to be considered in patients experiencing long-term CR after chemotherapy and biochemotherapy, such as haemangiomas which probably respond to anti-vascular endothelial growth factor (VEGF) treatment, although the published results are somewhat contradictory $[9,10]$. Nevertheless, the likelihood of benign tumours and vascular lesion is small if several imaging modalities point to malignant liver lesions, such as in the patient we describe.
In conclusion, although surgery remains the only curative option for a great majority of patients with CRC, there are rare patients who achieve long-term complete response and are probably cured after combined systemic therapy.

\section{References}

1. Benoist $\mathrm{S}$, Brouquet $\mathrm{A}$, Penna $\mathrm{C}$ et al. Complete response of colorectal liver metastases after chemotherapy: does it mean cure? J Clin Oncol 2006; 24(24): 3939-3945.

2. Elias D, Goere D, Boige $V$ et al. Outcome of posthepatectomy-missing colorectal liver metastases after complete response to chemotherapy: impact of adjuvant intra-arterial hepatic oxaliplatin. Ann Surg Oncol 2007; 14(11): 3188-3194.

3. Tanaka K, Takakura H, Takeda K et al. Importance of complete pathologic response to prehepatectomy chemotherapy in treating colorectal cancer metastases. Ann Surg 2009; 250(6): 935-942.

4. Adam R, Wicherts DA, de Haas RJ et al. Complete pathologic response after preoperative chemotherapy for colorectal liver metastases: myth or reality? J Clin Oncol 2008; 26(10): 1635-1641. doi: 10.1200/JCO.2007.13.7471.

5. Holubec L, Liška V, Fínek J. Význam časné nádorové regrese a hloubky léčebné odpovědi při hodnocení účinnosti systémové léčby metastazujícího kolorektálního karcinomu. Klin Onkol 2015; 28(2): 89-93. doi: 10.14735/amko201789.

6. Lang $\mathrm{H}$, Frilling $A$, Stoehlmacher J et al. Tumour response and secondary resectability of colorectal liver metastases following neoadjuvant chemotherapy with cetuximab: the CELIM randomised phase 2 trial. Lancet Oncol 2010; 11(1): 38-47. doi: 10.1016/S1470-2045(09)70 330-4

7. Folprecht G, Gruenberger T, Bechstein WO et al. Correlation of bevacizumab-induced hypertension and outcome in the BOXER study, a phase II study of capecitabine, oxaliplatin (CAPOX) plus bevacizumab as peri-operative treatment in 45 patients with poor-risk colorectal liver-only metastases unsuitable for upfront resection. Br J Cancer 2012; 106(11): 1718-1721. doi: 10.1038/bjc.2012.152.

8. Malavasi N, Ponti G, Depenni R et al. Complete pathological response in a patient with multiple liver metastases from colon cancer treated with Folfox-6 chemotherapy plus bevacizumab: a case report. J Hemat Oncol 2009; 2(1): 35. doi: 10.1186/1756-8722-2-35.

9. Mahajan D, Miller C, Hirose K et al Incidental reduction in the size of liver hemangioma following use of VEGF inhibitor bevacizumab. J Hepatol 2008; 49(5): 867-870. doi: 10.1016/j.jhep.2008.06.028.

10. Lee M, Choi JY, Lim JS et al. Lack of anti-tumor activity by anti-VEGF treatments in hepatic hemangiomas. Angiogenesis 2016; 19(2): 147-153. doi: 10.1007/s10456016-9494-9. 